\title{
To read or not to read? The politics of overlooking gender in the geographical canon
}

Article

Accepted Version

Creative Commons: Attribution-Noncommercial-No Derivative Works 4.0

Maddrell, A. (2015) To read or not to read? The politics of overlooking gender in the geographical canon. Journal of Historical Geography, 49. pp. 31-38. ISSN 0305-7488 doi: https://doi.org/10.1016/j.jhg.2015.04.013 Available at https://centaur.reading.ac.uk/71080/

It is advisable to refer to the publisher's version if you intend to cite from the work. See Guidance on citing.

Published version at: https://doi.org/10.1016/j.jhg.2015.04.013

To link to this article DOI: http://dx.doi.org/10.1016/j.jhg.2015.04.013

Publisher: Elsevier

All outputs in CentAUR are protected by Intellectual Property Rights law, including copyright law. Copyright and IPR is retained by the creators or other copyright holders. Terms and conditions for use of this material are defined in the End User Agreement.

www.reading.ac.uk/centaur

\section{CentAUR}


Central Archive at the University of Reading

Reading's research outputs online 
To read or not to read? Overlooking gender in the geographical canon

\author{
Avril Maddrell \\ avril.maddrell@uwe.ac.uk \\ Department of Geography and Environmental Management, University of the West of \\ England, Coldharbour Lane, Bristol BS16 1QY
}

Acknowledgments 
Full title: To read or not to read? Overlooking gender in the geographical canon

\title{
Running title: Overlooking gender in the geographical canon
}

\begin{abstract}
Wherever there is an established 'canon' within an established scholarly arena, this is near universally dominated by texts written by men. Whilst historical contextual reasons may account for the gendering of such knowledge production in relation to publications dating from the nineteenth and preceding centuries, one has to ask why this has persisted in an era of equal access to education and academia in the twentieth century. Why is women's work, highly influential in its day, overlooked in subsequent histories of the discipline and therefore marginalised in discussions of key works? These questions are particularly pertinent to any notion of a geographical canon, given its relatively late arrival as a degree award in the UK from 1917 onwards. This paper draws on an analysis of the significance of lineage, reviewing, reputation and genre in the contextualised production and reception of selected work to explore the merits and demerits of a geographical canon - and the implications for gendered geographical knowledge.
\end{abstract}

\section{Key words}

Gender reception engagement legacy 
To read or not to read? Overlooking gender in the geographical canon

\section{Introduction}

In a previous short intervention ${ }^{1}$, I highlighted four key points in relation to debates on canonical geographies. The first is a preference for the nomenclature of the 'classic' rather than 'canonical'. The second is the - by definition - selective and therefore exclusionary nature of any canon, notably, the under-representation of women's work from any geographical canon. Thirdly, the need for engagement with geographical work deemed significant for whatever reason; and finally a call to appreciate but also to look beyond key texts when framing the historical legacy of the discipline. In this paper these points provide the foundation for a more detailed analysis of canon formation in the UK and gives particular attention to i) the practices and implications of 'genre' preference, ii) degrees of engagement and iii) overlooking gender. To overlook has multiple meanings: to look over and survey or to 'have a view over'; to superintend; to ignore, fail to see, neglect; and to close one's eyes to, excuse, condone. Each of these meanings is pertinent to the following discussion.

A significant question to begin with is to ask why is there such interest in a geographical canon at this point in time? Influenced by Benedict Anderson's thesis on the formation of nation states as 'imagined communities' ${ }^{2}$, Kramnick suggests that the impetus to canon formation within a particular field may be in response to external stress or duress ${ }^{3}$. Is this current interest in a geographical canon an assertion of internal strength or a defensive reaction to external threats? As the collected papers in this special issue testify, interests and motivations vary, but it is worth noting that, in the UK context at least, the 2013 International Benchmarking Review of UK Human Geography reported a decline in the teaching of the history and philosophy of geography, despite research excellence in the field ${ }^{4}$. This has implications for current faculty and postgraduate recruitment to this subdiscipline and its future in the longer term. So one question we might reflect on is whether a stronger sense of canonical or classic texts could strengthen the raison d'être for the history and philosophy of geography in the undergraduate geography curriculum? Before returning to this strategic question it is necessary to consider the nature of a 'canon'. 


\section{Lessons from literature I: canon formation, lineage and genre}

'The literature we criticize and theorize about is never the whole. At most we talk about sizable subsets of the writers and workers of the past. This limited field is the current literary canon. ${ }^{5}$

Academic discussion of the notion of the canon has been much debated within the field of English literature, indeed, so hotly debated that the last twenty to thirty years have been dubbed as the 'canon wars' ${ }^{6}$. Consequently, the cut and thrust of these debates, as well as those undertaken in other disciplines, offer considerable insight to the nature of what is deemed canonical, the processes at play, and the implications of maintaining or challenging a discipline's canon. Key points from these debates are highlighted below.

Most discussions of any 'canon' explore the etymology of the term, including, variously, its origins as: a Greek Semitic word for a measuring rod or model; the authorised books which make up the Bible; Christian church law; and those recognised as saints within the church. Thus, canonical status has been associated not only with accolade but also with normative authority ${ }^{7}$, albeit an authority which, according to Frank Kermode, shifted in modern Western society from religion to a secular literary canon ${ }^{8}$; a shift which endowed the literary canon with a secular-sacred quality, with the associated attributes of moral and aesthetic authority. Each of these meanings associated with the canon has potential implications for our understanding of what constitutes the canon and the processes and impact of 'canonization'. Not surprisingly, it is the connotations of the term that make any 'canon' so contested'.

Within literature, the canon has been variously defined as 'a body of literary works traditionally regarded as the most important, significant, and worthy of study; those works ... considered to be established as being the highest quality and most enduring value, the classics.' ${ }^{10}$; the literary 'Art of Memory ... what has been preserved out of what has been written', based on what is considered 'authoritative' and 'crucial'11; an authoritative narrative that embodies and perpetuates the institutional transmission of orthodox values which underpin the cultural power of an elite ${ }^{12}$. 
In turn, the Canon is frequently associated with tradition and lineage, exemplified by F.R. Leavis' 'line of tradition' stretching from John Donne to T.S. Eliot ${ }^{13}$, whereby the mantle is passed across the generations, via an 'invisible hand' mechanism, whereby 'Greatness recognizes greatness and is shadowed by $i^{\prime}{ }^{14}$.

Canonicity is often explicitly or implicitly grounded in the notion of 'greatness'. indeed Harold Bloom made the self-fulfilling claim that 'All strong literary originality becomes canonical $^{\prime 15}$, emphasising originality, he argues that canonical status can often be attributed to: 'strangeness, a mode of originality that cannot be assimilated, or that so assimilates us that we cease to see it as strange ${ }^{16}$. Such discussions of greatness and originality echo replicate contemporaneous debates about 'firstness': what constitutes a first class degree in the humanities and social sciences, which frequently privileges something which is different and apparently innovative over careful scholarship.

Precisely who determines canonical status has been much debated. Bloom concluded that 'The deepest truth about secular canon-formation is that it is performed neither by critics nor academies, let alone politicians. Writers, artists, composers themselves determine canons, by bridging between strong precursors and strong successors ${ }^{\prime 17}$. A.S. Byatt echoes this view when she argues that 'A canon is ... what other writers have wanted to keep alive, to go on reading, over time ${ }^{18}$. For others, university teachers who determine curricula are vital gatekeepers of the canon; thus Jan Gorak summarises these multiple forms of canon into three key modes: i) a teaching guide; ii) a norm or rule; iii) a list of basic authorities ${ }^{19}$. Nick Turner provides a useful sense of the canon-in-practice in his description of it as the choices and value judgements which writers, readers and teachers make'20.

In an influential paper, Alastair Fowler identified a number of potentially overlapping canons: firstly, the official canon, i.e. that literature 'institutionalised' courtesy of its place in educational curricula and journalism, as well as attracting public patronage; secondly, an individual's personal canon: 'works [s] he happens to know and value'; thirdly, the potential canon of literature in its entirety; and fourthly, the accessible canon, i.e. that which is available and accessible ${ }^{21}$. Of course, the technological revolution of the last twenty years has had a huge impact on the latter, with implications for the second and third canonical 
forms, not least as online reviews, blogs and other forms of social media represent accessible vehicles for popular commentary on literature, politics and events.

Staying for the moment with what Fowler describes as the official canon (the most influential and therefore most contested), it is necessary to explore the notion and implications of such an institutionally-recognised body of work, not least because, as Fowler notes, any canon 'sets fixed limits to our understanding of literature'22. One assumption frequently asserted is that to be canonical, a work must have stood the test of time ${ }^{23}$, making any official canon inherently retrospective and conservative. Furthermore, this excludes the consideration of any current work and privileges those subjects and genres considered historical/ ahistorical or timeless, whether grand narratives or 'universal' aphorisms. In turn, and reflecting these attributes, canonical texts are frequently quoted, their lives and sphere of influence extended through these selective extracts, which give a particular mobility to the text, the quote being taken out of its context and applied to another, creating an often false sense of unproblematic continuity between past and present. As Clara Tuite has observed in relation to Jane Austen's work, 'The gesture of quotation removes Austen from the contingencies of a particular context. Canonicity breeds ahistoricity and an inescapable transhistoricity ${ }^{24}$.

Yet whilst often presented as 'timeless', the canon at a particular point in time reflects temporally and socially-situated preferences for particular genre, e.g. poetry over fiction. Thus, the hierarchy of genres changes over time ${ }^{25}$ and 'In each era, some genres are regarded as more canonical than others ${ }^{26}$. This fashion or preference for particular genres has significant implications for the status of an individual author or body of scholarship; as Fowler notes, 'generic changes help to shape canons of taste, and consequently of availability' and 'When a genre drops out of the repertoire altogether, reputations may be severely affected ${ }^{\prime 27}$. Another pertinent observation about genre is made by Nick Turner: authors who shift between genres or change the orientation of their work can lose both popular and scholarly following: 'writers who are hard to classify confuse the establishment as they cannot be easily taught ${ }^{28}$ - and, one might add, be pigeon-holed. Similarly, so-called transnational and trans-historical work often reflects the dominance of the English language, whereby 'global canonicity is achieved through the use of English, and connection with the United States' ${ }^{29}$; a point echoed by Jan Monk and others in relation to geography ${ }^{30}$. 
Whilst the process of canonization is a social process which needs to be seen in its institutional context, it is often an invisible one ${ }^{31}$. Whether designated as canonical or classic, there is a process involved, one of being approved, acknowledged, established as having intrinsic quality and value. Thus any canon formation represents not only 'a set of texts, but [also] a set of practices attributing value ${ }^{32}-$ a theme to which I will return.

As noted above, some indication of acclaim is often taken as a marker of what is 'worthwhile', worthy of our attention, and, in the case of books in particular, makes it more likely that we will select a particular book to read out of the vast pool of publications potentially available ${ }^{33}$. In literature this acclaim is frequently achieved through prizes, although endorsement also plays a role ${ }^{34}$. Prizes oscillate between functioning as 'lifetime achievement awards' and early career reputation-making ${ }^{35}$. Whilst prize winners are often treated as heroic figures, interest in the often equally-good short listed candidates may be short-lived. For example Turner cites the case of A.L. Barker whose work was endorsed as of the highest quality by Rebecca West and short listed for the Booker prize, but who 'has next to no scholarly work published on her ${ }^{36}$. He attributes this omission to both her genre (short stories) and the time lapse required in order to merit 'historical' attention or to be 'unearthed'. It might be added that in addition to her short stories, Barker also published eleven novels and won the first Somerset Maugham Prize in 1947; publishing short stories did not curtail Ernest Hemingway's reputation.

Where there is a relative absence of prizes for publications (as is the case in geography), we might look to citation indices and journals' tabs of the 'most read' and 'most downloaded' papers, as well as histories of the discipline: 'the most useful guide to who is favoured'37, and text book compilations of key readings, anthologies which represent 'the modern vehicle of the canon' ${ }^{38}$. Anthologies both reflect and shape what is taught in universities and schools, and illustrate the importance of the curriculum as a breeding ground for establishing and reiterating what is deemed worthy of study: 'reception secures value' and a place in any 'canon' ensures 'the terms of their reception were set for years to come'39.

However, Brian Corman has shown in the case of literature that Whiggish progressive histories of the novel result in the erasure of most women, despite critical success in their own day ${ }^{40}$, especially if their genre is disparaged more widely, as in the case of the 
eighteenth century novel, when women's novels were typically characterised as sentimental, didactic, Gothic or political, with the first two typically being excluded from the canon $^{41}$.

Repeated surveys or lists of the 'best', 'great', and 'Masters' of their subjects are overwhelmingly gendered. The Penguin 'Modern Masters' series, edited by Frank Kermode were all men; hence Lillian Robinson's assertion that the literary canon is 'an entirely gentlemanly artefact' reflecting men's preferences and consensus, and a wider sense of the canon transmitting orthodox values and reinforcing cultural power in the hands of a minority establishment ${ }^{42}$. While the 'Masters' series has now been replaced by the less gendered nomenclature such as 'Classics', 'The Times 50 Greatest Writers since 1945' published in 2008 included only 14 women and broadly echoed Malcolm Bradbury's selection in 'The Modern British Novel' published twenty five years earlier ${ }^{43}$. Reiteration is a powerful process. Whilst 'The enterprise of literary-critical history .... is to fix the peculiarities and particularities of those contexts. It works against the transhistorical assumption of an unproblematic continuity between the present and the past ${ }^{\prime 44}$. Disciplinary histories easily fall in to the trap of being reiterative of a lineage established in earlier works ${ }^{45}$ and anthologies can be equally reiterative, for example, there was a close correlation between the content of the Penguin Book of English verse first published in the 1950s and The Oxford Book of English Verse published forty years earlier ${ }^{46}$.

\section{Lessons from literature II: critics of the canon and alternative canons}

Frank Kermode identified the canonical as that which interprets the past in service of present needs, but that canonical texts and the canon itself are open to interpretation, not fixed in their meaning: 'Texts worthy of debate rather than beyond debate' ${ }^{47}$. In his examination of the canon in US fiction, Robert von Hellberg argued that canons are there to be 'opened up, demystified, or eliminated altogether' ${ }^{48}$. Arguably all canons - ecclesiastical or secular - are less consensual and uncontested than many assume ${ }^{49}$.

Contestation of literary and other canons was an inevitable consequence of the post-1960s growth of feminist, Marxist and Afro-American and post-colonial studies in North America 
and Europe. For example, Post-colonial scholar Edward Said critiqued the imperialist politics which underpinned an Orientalist canon ${ }^{50}$; and feminists such as Catharine Stimpson highlighted gendered exclusion: '... men as men, have controlled history, politics and culture. They have decided who will have power, and who will not; which realities will be represented and taught, and which will not. In doing so, men have neglected women, as women, to the margins of culture, if not silence and invisibility ${ }^{51}$

Whilst Said, as a critic of the then established canon, is credited not only with suggesting a more 'open' and inclusive approach to what is studied, but also with undertaking a worthy political project and in identifying an Orientalist canon at work, Jan Gorak contrasted this as 'something the 'canon-busters' [i.e. women] have often failed to do'52. Clearly in Gorak's view other critics who highlight gender and/or class-based biases in the canon are neither sufficiently scholarly in their critiques nor acting politically by doing so. Furthermore, Gorak claims to read Said's subtext: i.e. that Said wanted the canon reinterpreted rather than annihilated. While Said is credited with undertaking a political project, other critics of an established canon are not. The acerbic labelling of critics as 'canon-busters' 53 and dismissal of critics of the status quo as the 'School of Resentment' or an 'academic rabble's4 tell their own story, as does Bloom's response to the notion that 'We are all feminist critics', which for him represented 'rhetoric suitable for an occupied country, one that expects no liberation from liberation'55. Whilst Nick Turner argues that 'If there ever was such a thing as a closed literary canon with patriarchal gatekeepers, it is a thing of the past ${ }^{\prime 56}$, yet, echoing Olga Kenyon's query nearly twenty years earlier, he is still compelled to ask why women who were celebrated in their own day are now forgotten? ${ }^{57}$. The scope of what is considered to be 'good' literature has broadened considerably since the 1980s, resulting in multiple dynamic 'canons' reflecting the interests of different constituencies, hegemonic and counter-hegemonic, each with their own geographies, literal and metaphorical. However, even counter-hegemonic movements have their own hegemonies.

However, whilst critiques of the Western canon have shifted literary studies away from a singular monolithic and fixed canon towards a more inclusive, multiple and dialogic approaches, issues of representation and the social processes of establishing value persist. In terms of the (socio-economic) global majority, Pankaj Mishra argues that the intellectual and cultural life of the West has been 'enriched by the representatives of a long invisible 
majority', but continues, 'even if some of them pointed too stridently to discrepancies in the self-congratulatory narratives of powerful white men'58. Suffice to say that 'strident' is a term rarely applied to men, especially white men. Although, as Mishra suggests, after the passing of twenty plus years, views such as those held by Bloom might be seen as oldfashioned, but, like canonization, the taint of demonization can be difficult to shift. Today commentators continue to question whether reading lists, prizes, citation indices, histories and anthologies are representative of the demographic they originate from and that which they pertain to reach/influence. They also question what constitutes 'writing' deemed worthy of the canon, arguing that westernised assumptions which privilege particular forms and genres persist ${ }^{59}$; what about women (and men) whose oral presentations were transcribed by others, who translated other works, who wrote in various languages and countries? 'In these gray boundaries lie other potential narratives of women's literary history' ${ }^{60}$.

Given the persistent under-representation of women and other marginalised groups, biobibliographies (i.e. an inclusive form of anthology) can play an important role cataloguing women's (and other marginalised) work ${ }^{61}$, as can other media such as oral histories and storying, but these are not sufficient to the task of countering under-representation; it is not only about the scope and structure of publications and what we record, but also the practice and nature of engagement with such work and the structure of debate and enquiry which also needs consideration. In her discussion of 'American women writers and masculine tradition', Karen Kilcup argued for a 'soft canon', one that avoids gendered oppositions, favouring the exploration of connections, mutual influences and theories of difference and alliance ${ }^{62}$. This approach is contextual and relational, recognising the significance of intersectionality such as ethnicity, sexuality and class, in order to 'bring together these separate spheres of criticism and to create a more richly textured account ${ }^{\prime 63}$.

\section{Canonical lessons for geographical knowledge}

What observations can we make from these debates that are useful to understanding any notion of a geographical canon? Coming late to the canonical debate, numerous and varied critiques have challenged any notion of a singular monolithic or Whiggish geographical 
canon in favour of a more open, inclusive and dialogic approach. Geographical scholarship has not been constrained by a notion of a singular impermeable canon in the same way that some department's of English literature have been represented (notably Columbia's 'Great Books' curriculum). However, as I have argued at length in Complex Locations, UK Geography's disciplinary histories a) under-represent women's work which was influential in its day and b) tend to reiterate in successive accounts the work of only a handful of women, often represented as 'exceptional'. In the face of the relative decline of the teaching of the history and philosophy of Anglo-American geography, the more recent rise of anthologies of 'leading thinkers' might be seen as a better measure of contemporary status and engagement. However, in terms of proportion, geographical work undertaken by women fares little better in most of these anthologies ${ }^{64}$ - a yardstick to be aware of.

Given that any canon, whether institutionalised, alternative or popular, constitutes the 'limited field' we 'criticize and theorize about' ${ }^{65}$, whether a fixed or dynamic canon, 'classic' texts, work awarded critical accolades, prizes or a place in key anthologies, the question of collective critical engagement is key (Turner's 'the choices and value judgements which writers, readers and teachers make'66). Whilst engaging with high quality texts which merit re-reading is a keystone to any reading strategy, what Charles Withers describes as appreciating canonical texts without being enslaved to a (fixed) canon, we also need to be sensitive to the 'material and epistemological conditions that lie behind the making, shaping and consumption of texts ${ }^{67}$ Focusing on the post-publication life of scholarship, elsewhere, I have suggested that the reception of geographical work can be analysed via the three 'Rs': refereeing, reviewing and reputation and categorized by epistemological preferences (methodological and theoretical) ${ }^{68}$. Building on this, alongside the preceding analysis of canonical debates in literature, key ideas discussed here include the significance of genre, processes of reiterative citation and engagement and contemporary practices of lineage and veneration.

A more nuanced understanding of multiple, even competing, 'canons' and the social processes driving the 'canonization' of scholars and their texts within particular communities of scholarship provides insight to historical and contemporary patterns and 
processes of scholarship, engagement and citation in human geography. However, even multiple canons do not ensure an even representation of varying interest groups. Naturally those pursuing common research interests, forming communities of scholarship and praxis, know each other's work and operate within this sphere of influence and praxis as colleagues and cohorts of postgraduate students, mutually influencing research methods, theoretical frames, conference themes, patterns of citation and refereeing: what has often been referred to as a school of thought within a particular field. This reciprocal and selfreinforcing relationship has been nicely summarised in canonical terms as: 'communities designate canons and canons reproduce communities' ${ }^{\prime 69}$. However, such school formation can result in uncritical veneration, as Richard Powell pithily posits, 'Certain texts produced by certain geographers of older and of very recent date, have been treated sychophantically, and at worst as pseudo-gospel. They have been venerated, uncritically disseminated and in some cases treated as the writings of prophets. In short they are positioned as canonical'. ${ }^{70}$ This process of veneration can occur in minority, alternative or 'critical' communities, as much as any 'mainstream' community of scholarship. A litmus test for this is frequently to be found in the refereeing processes which are intended to act as quality assurance in academic publications: is it possible to discuss $X$ without being required by referees to refer to work by $A$ ? If so, is this because A's work is vital to discussing $X$, or is it a case of what Jan Monk refers to as 'ritual citings' ${ }^{71}$, i.e. because $X$ is broadly deemed to be $A^{\prime}$ s intellectual territory and therefore requires tribute in the form of citation and discussion? Or more cynically, because referee Q's own research interests and/or reputation are linked to that of $A$ ? At the same time, is it possible, to get through the review process without referring to, or only superficially acknowledging, the work of $B, C$, and D who also work on $\mathrm{X}$, and if so, why is that? Because their work is not relevant, or because no one will give voice to, insist on, its relevance? By such mechanisms, increasingly audited through citation indices etc., (individual, departmental, sub-discipline, doctoral cohort, journal) reputations are reinforced, whilst others are marginalised. Ron Johnston has likewise highlighted the practice of 'citing without sighting' existing scholarship, ${ }^{72}$ but more than this, citation alone does not necessarily constitute scholarly engagement: in the case of gendered under-representation, 'it is not enough to reference women's geographical work, it is necessary to critically engage with that work, past and present' in order to produce more representative accounts of influential work within the field of geography ${ }^{73}$. 
Whilst traces of reviewers' comments on manuscripts may be found in journal and publishers' archives or occasionally in author's personal papers or commentaries, book reviews constitute a more public evaluation of publications. Published reviews, as with other forms of reception, vary across time, geographical and social contexts. ${ }^{74}$ They can do much to alter the reputation of both the reviewed and the reviewer, especially if a reviewer is bent upon establishing their own reputation through 'giant-slaying' or laying the ghosts of former epistemologies to rest, not least because, as Karen Kilcup noted, it is easier to establish academic authority and 'presence' through an adversarial style rather than a dialogic one $e^{75}$ - a theme to which I will return in the conclusion.

Historical geographer, Dorothy Sylvester, researched and published at the overlap of several disciplinary boundaries and continued to publish up to and beyond her retirement, characteristics which could represent canonical or marginal status, depending not only upon the quality of her work, but also on the vested interests of those following her work. Her 1969 publication of The Rural Landscape of the Welsh Borderland three years after her retirement could be seen as a culmination of over thirty years work on the region. The book was favourably reviewed by Sylvester's contemporary E.W. Gilbert, but whilst the depth of research was recognised by one young reviewer, it was rapidly undercut as methodologically old-fashioned, a 'latter-day example of the work of the first generation' of historical geographers, and compared unfavourably with a recent edited collection of innovative historical work by multiple authors, including the reviewer's professed 'heroes'76. This is not to suggest that the critiques were necessarily unjustified, but rather to highlight the ways in which the review process can dismiss and relegate a lifetime's scholarship in favour of promoting an alternative epistemology, as well as being illustrative of both academic networks and allegiances at play, and personal reputation-formation.

This example also links to debates about genre within discussions of the literary canon. Within geography the idea of genre might be applied to particular paradigms or schools of geographical knowledge, including theoretical or conceptual frames of reference, particular themes or issues, and methodological approaches. While geographical work is not characterised by 'genre' per se, sub-disciplines and particular epistemological/ conceptual frameworks serve to define cohorts of work, e.g. economic, political and regional geographies, or post-structuralist, feminist and non-representational geographies. In the 
context of human geography, such preferences, combined with a tendency to reject wholesale preceding modes of geographical enquiry, can be seen in the dismissal of certain epistemologies, notably regional geographies, which dominated British and European human geography prior to the 1960s as well as the more recent marginalisation of spatial science ${ }^{77}$. Thus, geography has tendency to 'move with the times' intellectually and methodologically, often to the detriment of the reputations of preceding individuals, research cohorts and epsitemologies ${ }^{78}$. Such shifts in recognition and status produce a process of double-obfuscation: a veil is drawn across the earlier significance of the body of work as a whole, and the work of leading individuals in that field is simultaneously devalued and obscured from view. A large body of regional geographical work has been excised from collective geographical consciousness in this way. While the concept and scale of the 'region' was contested, and there were analytical and conceptual weaknesses in some of this work by today's standards, a deep knowledge of relationships between people and their local environment, grounded in in-depth field work, could be found, but has been largely overlooked (something which may be corrected or re-inscribed by the emergence of ' $N$ N' Regional Geographies). The longevity of the broad (if dynamic) regional methodological and analytical frame resulted in key texts extending their influence over successive generations of students and researchers, as was the case with Hilda Ormsby's 1931 France. A Regional and Economic Geography. As the most popular text on France in English, which remained in print and wide use for over thirty years ${ }^{79}$, as well as, to my knowledge, being the first geography text to assert a claim for 'economic' rather than 'commercial' geography, it was, without doubt, an important 'Classic' text.

At the same time, other particular modes or frames of work have been privileged e.g. theoretical and political work. Whilst political novels were dismissed as a 'feminine' genre in the eighteenth and nineteenth centuries ${ }^{80}$, Turner suggests that many female authors attracting critical attention in recent years have done so because of the political aspects of their fiction e.g. Doris Lessing. On the other hand, in her survey 'Contemporary Women Novelists', Olga Kenyon suggests that women who do not foreground issues of contemporary interest get passed over - overlooked - simply not deemed worthy of critical attention. Comparing the relative disciplinary presences of Halford Mackinder and E.G.R. Taylor is pertinent here. He is particularly noted for being appointed to the first Readership 
in Geography at the University of Oxford (1887); Taylor as the first woman promoted to a professorship in geography, at Birkbeck College, University of London (1930). Both grew to great influence in their day, Mackinder wrote a modest number of publications and combined his academic appointments with serving as a Member of Parliament; Taylor (who completed the Oxford diploma in geographer after a B.Sc. in Chemistry) combined her academic appointments with motherhood and wrote 150 publications throughout her career, continuing to research in to retirement. Both were committed to adult education and, typically for the era, wrote school texts as well as academic papers. While the work and influence of both are discussed in histories of the discipline up to the 1980s, since the 1990s Mackinder's geographical work, notably his commentaries on geopolitics and his expedition to climb Mount Kenya to avoid being labelled an 'armchair geographer', while Taylor's extensive innovative research on Tudor, Stuart and Hanoverian geographies of trade and Empire and associated technologies of navigation were largely passed over, despite her work being described as 'brilliant' by the RGS and biennial lectures being given in her honour since the 1960s. There are many factors at play, more than can be discussed here, which could account for the disparity between degrees of critical engagement between these two, but the key factors I would like to highlight here are synchronisation with contemporary interests and gendered memories. Both geopolitics and the Victorian Britain's period of high Empire fascinated political and historical geographers in the 1990s, while earlier technologies of navigation and periods of British Realpolitik did not. Also, While Mackinder died in 1947, leaving enough time for his personal politics and foibles tofade from living memory, Taylor, who died in 1966 and was publishing up to her death, is still remembered today, principally for her acerbic intellect and 'take no prisoners' approach to academic debate - characteristics rarely attributed in print to male colleagues with similar anecdotal reputations ${ }^{81}$. While Taylor's work was lauded in her own lifetime (as was Mackinder's), within historical geography, the sub-discipline she did so much to shape, it was soon deemed unfashionable, succeeded by the hegemony of Clifford Derby's school of Domesday-focused scholarship, including work by Taylor's former student, Eila Campbell.

The question of contemporary significance could shed light on why a few women working in particular sub-disciplines of geography have attained critical acclaim - canonization - whilst high quality work by women in other sub-disciplines fails to gain critical attention. However, 
genre-preferences do not account for all omissions or marginalisation of women's geographical work; as Mona Domosh ${ }^{82}$ pointed out these absences may be by dint of omission (a case of unknowing overlooking) or by commission (a matter of deliberate neglect or closing one's eyes to, and even condoning the absence). Hence the need for theoretically-informed 'more-than-contextual' analysis of geography's historiography, not least - but not only - feminist-informed analyses of women's absences and presences. Here Domosh's interrogation of the tensions between (British) cultural geographers focusing on the elite Western Canon of art, architecture and literature and feminist geographers concerned with past and present social exclusion and activism may shed some light on historical geographies and geography's historiography. These tensions which shape the 'intellectual contours of the subject' can reflect the inevitable intellectual and political interests of cohorts, but also, less appealingly can reflect a deliberate overlooking of those questions/topics/ methods which challenge one's vested interests, including those associated with one's intellectual lineage and associated spheres of contact and influence, including citation circles and employment networks. In methodological terms, notably inclusivity and scope, as well as conceptual and analytical insight, historical geographies, including historiographical consideration of the canon, still have much to gain from feminist approaches, not for lack of the arguments being made, but for lack of consistent consideration of and engagement with them. Gradually historiographical accounts become more inclusive in scope, but are intellectually hobbled, limited to the 'add women and stir' approach, if they do not consider the theoretical/ analytical import of gendered socialisation and patriarchal power relations as well as other relevant axes of power/difference.

\section{Concluding comments and questions}

In this consideration of the canonical within geography, the dual focus has been on the historiography of geography and contemporary practices, both of which illustrate gendered patterns of (under)representation. In both past and present, women have produced innovative and influential geographical work, but these have not been fully represented in disciplinary histories or contemporary anthologies. Whilst current interests inevitably influence our engagement with the past, it is necessary to look at work in the context of its own period in order to appreciate its significance in shaping the practice of geography in the past. Furthermore, if we can move beyond blinkered presentism when regarding earlier 
geographical work, understanding epistemological shifts between past and present can provide significant insight to, and prompt us to reflect on current priorities and practices, and any power relations which may underpin them. Overlooking the discipline as a whole shows that just as women are under-represented in promoted posts in British geography departments, they are still under-represented in all 'canonical' formats within the discipline (histories, anthologies, prizes), such overlooking has implications for gendered geographical knowledge. A more gender-balanced account of work considered to be first class in its day, and today, would represent a major step towards a more democratic subject, which also needs a more 'enhanced sensitivity to other forms of underrepresentation' within the discipline ${ }^{83}$. Much can be learned from Tuite's idea of a 'soft canon'; based on critical engagement, but engagement which is less adversarial, more nuanced. This offers both a permeable and dynamic approach which could include both a wider notion of significant geographical work to include non-textual forms, such as teaching and field work ${ }^{84}$.

In order to move towards this goal, a number of questions merit reflection:

- What bears / reaps rewards for re-reading?

- How can predominantly text-based sources be enriched by alternative sources, records and media?

- In the face of a huge potential canon, what is accessible, what part of that is the official canon, what part one's personal canon?

- Are those we read (and ourselves as authors) generous in acknowledging the work of others - part of a virtuous rather than vicious cycle of citation?

- To what extent do our individual and collective reviewing practices re-inscribe our own interest group and 'ritual citings' or broader, more inclusive, scholarship?

- What are the current 'measuring rods' in geographical work which establish current 'canons' (hegemonic and counter-hegemonic), those works one is simply not allowed not to cite?

- Are the works one is required to cite, works of excellence and insight or fashionable genre?

- To what extent do other contributors to this special issue address the issues raised here or are the politics of gendered knowledge production and status ghettoised? 
- Who will engage with this paper? Will it be overlooked?

Thus, coming full-circle to lessons from canonical debates within English literature reminds us of the central role of politics. Harold Bloom noted that any defence or assault on a received canon is political; while Catharine Stimpson argued that it is necessary to 'act, politically and culturally, in order to change history. Theory and practice must meet, engage each other, wed'. By contrast maintaining the status quo often needs less action. Bloom's strategy in the face of pressures to make the literary canon more inclusive was, like Lampedusa's The Leopard, to 'Change everything just a little so as to keep everything the same $^{\prime 85}$. Can the same be said of reflections on the historiography of geography? It may be strategically beneficial to the status of the sub-discipline of the history and philosophy of geography to designate a rubric for of canonical/ classical work, but it will be of limited value if it simply reiterates a narrow range of vested interests and re-inscribes the power relations of the past, including the over-dominance of the text. 


\section{REFERENCES}

${ }^{1} \mathrm{~A}$. Maddrell, Treasuring classic texts, engagement and the gender gap in the geographical canon, Dialogues in Human Geography 2, (2012) 324-327.

2 B. Anderson, Imagined Communities, London, 1983.

${ }^{3}$ J. B. Kramnick, The making of the English canon, PMLA 112, (1997) 1087-1101.

${ }^{4}$ ESRC-AHRC/ RGS-IBG, International Benchmarking Review of UK Human Geography, 2013.

${ }^{5}$ A. Fowler, Genre and the literary canon, New Literary History 11, (1979) 97-119 [97].

${ }^{6}$ N. Turner, Post-war British Women Novelists and the Canon, London and New York, 2010 [11].

${ }^{7} \mathrm{H}$. Bloom, The Western Canon the Books and School of the Ages, London, 1994.

${ }^{8}$ F. Kermode, Forms of Attention, Chicago, 1985; J. Gorak, The Making of the Modern Canon: Genesis and Crisis of a Literary Idea, London, 1991.

${ }^{9}$ Turner, Post-war British Women (note 6).

${ }^{10}$ Turner, Post-war British Women (note 6), 13.

${ }^{11}$ Bloom, Western Cannon (note 7), 17.

${ }^{12} \mathrm{~J}$. Gorak, The Making of the Modern Canon: Genesis and Crisis of a Literary Idea, London, 1991.

${ }^{13}$ Gorak, Modern Cannon (note 11).

${ }^{14}$ Bloom, Western Cannon (note 7), 10.

${ }^{15}$ Bloom, Western Cannon (note 7), 22, 25.

${ }^{16}$ Bloom, Western Cannon (note 7), 3.

${ }^{17}$ Bloom, Western Cannon (note 7), 522.

${ }^{18}$ A.S. Byatt, 2001,2 cited by Turner, Post-war British Women (note 6), 21.

${ }^{19}$ Gorak, Modern Cannon (note 11).

${ }^{20}$ Turner, Post-war British Women (note 6), 1. 
${ }^{21}$ Fowler, Genre (note 5), 98.

${ }^{22}$ Fowler, Genre (note 5), 98.

${ }^{23}$ Altieri,1984, cited by Turner 2010, p21; F. Kermode, Forms of Attention, Chicago, 1985

${ }^{24}$ C. Tuite, Sexual Politics and the Literary Canon, Cambridge, 2002 [2].

${ }^{25}$ Fowler, Genre (note 5).

${ }^{26}$ Bloom, Western Cannon (note 7), 20.

${ }^{27}$ Fowler, Genre (note 5), 111, 113.

${ }^{28}$ Turner, Post-war British Women (note 6), 137.

${ }^{29}$ Turner, Post-war British Women (note 6), 138.

${ }^{30} \mathrm{~J}$. Monk, Canons, classics, and inclusion in the histories of geography, Dialogues in Human Geography 2, (2012) 328-331; A. Maddrell, Treasuring classic texts, engagement and the gender gap in the geographical canon, Dialogues in Human Geography 2, (2012) 324-327.

${ }^{31}$ Turner, Post-war British Women (note 6).

${ }^{32}$ Tuite, Sexual Politics (note 24 )m my emphasis.

${ }^{33}$ Turner, Post-war British Women (note 6).

${ }^{34}$ Turner, Post-war British Women (note 6).

${ }^{35}$ Turner, Post-war British Women (note 6).

${ }^{36}$ Turner, Post-war British Women (note 6), 4.

${ }^{37}$ Turner, Post-war British Women (note 6), 4.

${ }^{38}$ Munn, 2001, 25 cited by N. Turner, Post-war British Women Novelists and the Canon, London and New York, 2010 [22].

${ }^{39}$ Kramnick, English Cannon (note 3), 1087.

${ }^{40}$ B. Corman, Women novelists before Jane Austin: the critics and their canons, Toronto, 2008.

${ }^{41}$ Corman, Women Novelists (note 39).

${ }^{42}$ Gorak, Modern Cannon (note 11), 1.

${ }^{43}$ The Times 5/1/2008; M. Bradbury, The Modern British Novel, London, 1983; N. Turner, Post-war British Women Novelists and the Canon, London and New York, 2010.

${ }^{44}$ C. Tuite, Sexual Politics (note 24), 44. 
${ }^{45}$ A. Maddrell, Complex Locations: Women's Geographical Work in the UK 1850-1970, Chichester, 2009.

${ }^{46}$ Fowler, Genre (note 5).

${ }^{47}$ Gorak, Modern Cannon (note 11), 155.

48 R. von Hellberg, Canons, Chicago and London, 1984.

${ }^{49}$ Gorak, Modern Cannon (note 11).

${ }^{50}$ E. Said, Orientalism, New York, 1978. E. Said, The world, the text, the critic: secular criticism, London, 1983.

${ }^{51}$ C. Stimpson, Introduction, in: S. Benstock, (Ed) Feminist issues in literary scholarship, Bloomington, 1987, 1-6 [2].

52 Gorak, Modern Cannon (note 11), 186.

${ }^{53}$ Gorak, Modern Cannon (note 11).

${ }^{54}$ Bloom, Western Cannon (note 7).

${ }^{55}$ Bloom, Western Cannon (note 7), 16.

${ }^{56}$ Turner, Post-war British Women (note 6), 44.

${ }^{57}$ Turner, Post-war British Women (note 6); O. Kenyon, Contemporary Women novelists, Ann Arbor, MI, 1991.

${ }^{58}$ P. Mishra, How would a book like Harold Bloom's 'Western Canon' be received today? Sunday Book Review, The New York Times, 18/3/2014.

${ }^{59}$ N. Al-Shalabi, F.A. Salameh, Q. Thebyan and K. Umari, The American literary canon: impervious to change?, International Forum of Teaching and Studies 7, (2011) 50-55; J. Buschsbaum, Academic Libraries and the remaking of the canon; Implications for collection development librarians, Library Philosophy and Practice (e-journal), Paper 266, (2009); E. Said, The world, the text, the critic: secular criticism, London, 1983.

${ }^{60} \mathrm{H}$. Hoogenboom, Bibliography and national canons: women writers in France, England, Germany, and Russia (1800-2010), Comparative Literature Studies 50, (2013) 314-341, 316.

${ }^{61} \mathrm{H}$. Hoogenboom, Bibliography and national canons: women writers in France, England, Germany, and Russia (1800-2010), Comparative Literature Studies 50, (2013) 314-341. 
${ }^{62}$ K.L. Kilcup, Soft Canons: American Women Writers and Masculine Tradition, lowa, 1999.

${ }^{63}$ Kilcup, Soft Canons (note 61), 1.

${ }^{64}$ Maddrell, Complex Locations (note 45); Maddrell, Treasuring classic texts (note 1).

${ }^{65}$ Fowler, Genre (note 5), 97.

${ }^{66}$ Turner, Post-war British Women (note 6), 1.

${ }^{67}$ C.W.J. Withers, Geography's evolving traditions and textual critique, Dialogues in Human Geography 2, (2012) 317-320.

${ }^{68}$ Maddrell, Complex Locations (note 45), 333.

69 I. Keighren, C. Abrahamsson and V. della Dora, On canonical geographies, Dialogues in Human Geography 2, (2012a), 296-312, 299.

${ }^{70}$ R. Powell, Questions on the canon? Dialogues in Human Geography 2, (2012), 338-340, 340.

${ }^{71}$ Monk, Canons, classics, and inclusion, (note 65).

72 R.J. Johnston, Review of Bringing geography to book: Ellen Semple and the reception of geographical knowledge, by Innes M. Keighren. Journal of Historical Geography 37, (2011) 244-245.

73 Maddrell, Complex Locations, (note 45), 339.

${ }^{74} \mathrm{I}$. M. Keighren Bringing geography to book: Ellen Semple and the reception of geographical knowledge, London, 2010; Maddrell, Complex Locations, (note 45)

75 Kilcup, Soft Canons (note 62).

${ }^{76}$ D. Sylvester, The Rural Landscape of the Welsh Borderland: a study of Historical Geography, London, 1969; E.W. Gilbert, Review: The Rural Landscape of the Welsh Borderland: a study of Historical Geography, Geographical Journal 136, (1970), 260-1; M.J. Bowden, Review: Three generations of British Historical Geography, Economic Geography 48, (1972), 214-16; Maddrell, Complex Locations (note 45), 219-222.

77 A. Maddrell, Revisiting the region: 'ordinary' and 'exceptional' regions in the work of Hilda Orsmby 1917-1940, Environment and Planning A 38, (2006) 1739-52; Maddrell, Treasuring classic texts (note 1); Maddrell, Complex Locations (note 45); R. Johnston, The politics of changing human geography's agenda: text books and the representation of increasing diversity, Transactions of the Institute of British Geographers, NS 31, (2006), 286-303. 
${ }^{78}$ See Keighren et al, op. cit. (note 72 ) and other contributions to the special issue.

${ }^{79}$ Maddrell, op. cit.

${ }^{80}$ Corman, Women Novelists (note 39).

${ }^{81}$ Maddrell, op. cit. (note 46); A. Maddrell and H. Clout, E.G.R. Taylor, in C. Withers and H. Lorimer (eds.) Geographers Biobibliographical Series 30 (2012), Edinburgh.

${ }^{82}$ M. Domosh, An Uneasy Alliance? Tracing the Relationships between Feminist and Cultural Geographies, Social Geography 1 (2005), 37-41; M. Domosh and K. Morin, Travels with Feminist Historical Geography, Gender, Place and Culture 10 (2003), 257-264.

${ }^{83}$ Maddrell, op. cit. (note 46).

${ }^{84}$ Maddrell, Complex Locations (note 45); Maddrell, Treasuring classic texts (note 1); J. Monk, Canons, classics, and inclusion in the histories of geography, Dialogues in Human Geography 2, (2012) 328-331.

${ }^{85}$ Stimpson, Introduction, (note 53), 2; Bloom, Western Cannon (note 7), 16, my emphasis. 